\title{
Emerging assessment tools to inform food system planning
}

\author{
Julia Freedgood, ${ }^{a}$ Marisol Pierce-Quiñonez, ${ }^{b}$ Kenneth A. Meter ${ }^{c}$
}

Submitted 29 April 2011 / Accepted 28 October 2011 / Published online 23 December 2011

Citation: Freedgood, J., Pierce-Quiñonez, M., \& Meter, K. A. (2011). Emerging assessment tools to inform

food system planning. Journal of Agriculture, Food Systems, and Community Development, 2(1), 83-104.

http://dx.doi.org/10.5304/jafscd.2011.021.023

Copyright (C) 2011 by New Leaf Associates, Inc.

\begin{abstract}
Food system planning is an emerging field engaging planners and planning organizations, civic leaders, citizens, food policy councils, and others interested in creating more sustainable food systems. Planning practices are being developed to address the complex soil-to-soil food system, which spans production to consumption to reuse and recycling of waste. Community engagement is critical to fostering interactions within the full
\end{abstract}

\footnotetext{
${ }^{a}$ Managing Director, Farmland \& Community Initiatives, American Farmland Trust, $120018^{\text {th }}$ Street NW, Suite 600, Washington DC 20036 USA; +1-202-378-1205; ifreedgood@,farmland.org

b Corresponding author: Marisol Pierce-Quiñonez, M.A. candidate in Urban \& Environmental Policy and Planning, and M.S. candidate in Agriculture, Food \& Environment. Tufts University, 97 Talbot Avenue, Medford, MA 02144 USA; Marisol.pierce_quinonez@tufts.edu

c President, Crossroads Resource Center, 7415 Humboldt Avenue S., Minneapolis, MN 55423 USA; kmeter@,crcworks.org
}

spectrum of food system stakeholders — from farmers and ranchers to planners and local officials to individual and institutional consumers. A growing body of assessment tools is being developed to inform this process. As most of these tools are relatively new, there is little research that addresses the different methodologies or evaluates their use as planning tools. This paper outlines a variety of approaches and suggests further research to evaluate their efficacy.

\section{Keywords}

community food assessment, comprehensive planning, food system assessment, food system planning, food systems evaluation, foodsheds, local food and farm economies

\section{Background}

Food system planning is an emerging field that engages citizens, food policy councils, planning professionals, civic officials, and others interested in creating more sustainable food systems. While many disciplines within the planning profession 
have established best practices that span data collection methods, visioning, design charettes, and community decision-making, planners are only beginning to develop practices that address the complex soil-to-soil food system, which spans from production to consumption to reuse and recycling of waste. Similarly, while people engaged in sustainable agriculture have addressed food system issues for many years, they could gain insights from the planning field, which emphasizes systems-based approaches and relies heavily on data assessment and community engagement tools.

As recently as 2000, Kameshwari Pothukuchi and Jerome Kaufman pointed out that the food system is "notable by its absence from most planning practice, research, and education" (p. 113). Despite the fact that planning practice is "concerned with community systems - such as land use, housing, transportation, the environment, and the economy — and their interconnections" (Pothukuchi \& Kaufman, p. 113), until 2008 food was not included in mainstream planning activities. When it did occur, planning efforts typically were led by food system stakeholders and people working in fields related to sustainable agriculture and community food security. As one example, the Leopold Center at Iowa State University published a guide for citizen groups entering into local food system planning (Pirog et al., 2006).

In 2007, the American Planning Association (APA) addressed this gap in planning practice with its Policy Guide on Community and Regional Food Planning, which stated, "Yet among the basic essentials for life — air, water, shelter, and food — only food has been absent over the years as a focus of serious professional planning interest. This is a puzzling omission because, as a discipline, planning marks its distinctiveness by being comprehensive in scope and attentive to the temporal dimensions and spatial interconnections among important facets of community life" (p. 1). Since then, food system planning has emerged as an exciting new field that is beginning to connect agricultural land use with economic development, public health, community food security and, to a lesser extent, environmental protection.
At its best, food system planning addresses the entire life cycle of food: from natural resource management and the cultivation of crops and livestock, through processing, packaging, and distribution of food, to acquisition and consumption at homes, cafeterias, and restaurants, and ending with disposal in a waste facility or reuse as compost applied to a field. More typically, food planning addresses a narrow part of this spectrum. As a result, each plan has a different mission and a different emphasis. For example, hunger advocates tend to focus on food security, public health focuses on obesity, farmland protection groups highlight the land base needed to support local or regional diets, and economists generally concentrate on job creation and economic development.

Since 2010, however, a flurry of new food system plans have been released in various parts of the country that address everything from farmland protection to healthy food access — integrating, for example, the prevailing public costs for foodrelated disease into new economic opportunities, and fashioning community wealth-creation opportunities in low-income neighborhoods. Many address food justice concerns as well. Despite a lack of low-income participation in existing alternative agri-food movements (Guthman, 2006), planners often employ tools such as communitybased assessments and stakeholder participation to incorporate the needs of all individuals. While in the past most plans focused on parts of the food system rather than the whole system, some of the newer plans are truly comprehensive and increasingly are supported by thorough data analysis.

Since many of the assessment tools used to inform these plans are new, there is little objective evaluation of their efficacy. However, their futureoriented nature and focus on assets and liabilities make them similar to other assessment tools that are used at the beginning stages of the professional planning process. Needs assessments may be useful in prioritizing public policy in the areas of greatest need (Percy-Smith, 1996). Environmental impact assessments are required by law to determine the effect of new plans (Nagarajan, 1999), and are valuable tools for promoting sustainable develop- 
ment (Benson, 2003). Health impact assessments are useful both in the creation of plans and to traditional planning outcomes such as contributing to social capital and institutional change (Slotterback, 2011). These assessments have all contributed information to the planning process and facilitated collaborations across disciplines, suggesting that similar assessments of the food system should prove valuable for the beginning stages of food systems planning.

Different tools can help diverse interests develop plans and policies to achieve their goals. With their interdisciplinary systems training and cross-sectoral work, planners are well suited to work with communities and multiple stakeholders to build sustainable food systems that address all of these interests together. Planners are trained in the political process and in ways to facilitate incorporating stakeholder involvement at all levels of policymaking. Whether leading or supporting, planner engagement in food system efforts brings valuable perspectives and methods to the table, as they are trained to solicit community involvement and often have proprietary data sets that can be of value to comprehensive food system assessments. Assessment tools are needed to support community as well as professional efforts to create safe, secure and resilient food systems.

The following sections outline tools that planners, as well as professional and community advocates for sustainable food systems, are using to support food system planning efforts. Examples are not comprehensive, but demonstrate what is addressed in a typical assessment of each type. Two of the newest types of assessments, foodshed and food system assessments, are noted first because of their increasing use and appeal to local and regional food system planning.

A variety of assessment tools have been used in recent years that bring food system and planning professionals together to establish a baseline of information and set goals for comprehensive food system planning efforts. These tools vary in methodology and scope, and as such define the problems associated with contemporary food systems differently. This paper attempts to catalogue the different types of assessments currently in use, in order to provide food system planners with an understanding of the tools available to assist them.

So far, there are no agreed-upon definitions of assessment typologies that differentiate one tool from another, and sometimes one assessment tool will fit into more than one category. This article represents one of the first attempts to separate the different assessments into typological categories. Table 1 lists exemplary assessments along with summary characteristics, such as their key purposes and methodologies. It also presents profiles of a few "typical" reports that demonstrate both the strengths and weaknesses of different assessment tools.

\section{Foodshed Assessments}

Based metaphorically on the concept of a watershed, ${ }^{1}$ a "foodshed" is a way to identify the geography of prevailing or future sources of food for a given region, or to trace the movement of food from agricultural regions to a specified population center. Ultimately drawn from John Wesley Powell's classic 1878 definition of a watershed, “...within which all living things are inextricably linked by their common water course and where, as humans settled, simple logic demanded that they become part of a community," Kloppenburg, Hendrickson, and Stevenson (1996) describe a foodshed as a "unifying and organizing metaphor for conceptual development that starts from a premise of the unity of place and people, of nature and society" (p. 34). As such, a foodshed is a conceptual framework to connect communities with the agricultural land base needed to produce food to support them, but given that food travels by boat, truck, and airplane, foodsheds are not strictly a natural resource definition in the same way as are watersheds. Still, taking poetic license, the term has

\footnotetext{
${ }^{1}$ According to the EPA, a watershed is the "area of land where all of the water that is under it or drains off of it goes into the same place....Watersheds come in all shapes and sizes. They cross county, state, and national boundaries" (http://water.epa.gov/type/watersheds/whatis.cfm). There are 2,267 watersheds in the United States.
} 
Table 1: Categories of Food System Assessments

Note: This list is not necessarily exhaustive. Moreover, categories are not completely separable. Any given food assessment may include elements from one or more of these types.

\begin{tabular}{|c|c|c|c|c|}
\hline Assessment Type & Purposes & Methodologies & Limitations & Selected Examples \\
\hline $\begin{array}{l}\text { Local or Regional } \\
\text { Foodshed } \\
\text { Assessment }\end{array}$ & $\begin{array}{l}\text { Determine the existing } \\
\text { or potential geographic } \\
\text { boundaries of local food } \\
\text { procurement; identify } \\
\text { the land requirements } \\
\text { for feeding a given } \\
\text { population. }\end{array}$ & $\begin{array}{l}\text { Geospatial analysis of } \\
\text { soils data, land use } \\
\text { characteristics, produc- } \\
\text { tion levels and capacity, } \\
\text { and consumption } \\
\text { estimates. }\end{array}$ & $\begin{array}{l}\text { - "Foodshed" is more conceptual } \\
\text { than actual. } \\
\text { - Local consumption data is not } \\
\text { readily available. } \\
\text { - External forces beyond geo- } \\
\text { graphic boundaries often are not } \\
\text { considered. } \\
\text { - Key food system infrastructure } \\
\text { often is not addressed. }\end{array}$ & $\begin{array}{l}\text { - Testing a complete-diet model for estimating the } \\
\text { land resource requirements of food consumption } \\
\text { and agricultural carrying capacity: The New York } \\
\text { State example. New York. (Peters et al., 2009) } \\
\text { - Local foodshed mapping tool. New York. (Cornell } \\
\text { University Cooperative Extension, 2010) } \\
\text { - Think globally, eat locally: San Francisco } \\
\text { foodshed assessment. California. (Thompson, } \\
\text { Harper, \& Kraus, 2008) } \\
\text { - Assessing the local food supply capacity of } \\
\text { Detroit, Ml. Michigan. (Colasanti \& Hamm, 2010) }\end{array}$ \\
\hline $\begin{array}{l}\text { Comprehensive } \\
\text { Food System } \\
\text { Assessment }\end{array}$ & $\begin{array}{l}\text { Analyze the systemic } \\
\text { nature of a local, state, } \\
\text { or regional food system, } \\
\text { including the land } \\
\text { requirements, produc- } \\
\text { tion, processing, distri- } \\
\text { bution, consumption, } \\
\text { and disposal of waste. } \\
\text { Addresses the inter- } \\
\text { actions of food with } \\
\text { social, environmental, } \\
\text { and economic concerns. }\end{array}$ & $\begin{array}{l}\text { Quantitative and quali- } \\
\text { tative, often including } \\
\text { geospatial analysis of } \\
\text { soils data, land use } \\
\text { characteristics, food } \\
\text { production and con- } \\
\text { sumption, and related } \\
\text { topics, such as histori- } \\
\text { cal trends and life cycle } \\
\text { analysis of the food } \\
\text { system. Qualitative } \\
\text { analysis of stakeholder } \\
\text { focus groups, surveys } \\
\text { and interviews. }\end{array}$ & $\begin{array}{l}\text { - Conceptual and methodological } \\
\text { approaches to "systemic" work } \\
\text { are not always made explicit. } \\
\text { - Holistic assessments are expen- } \\
\text { sive, but it is misleading to } \\
\text { address parts of the system and } \\
\text { represent them as the whole. } \\
\text { - Systems analysis may be viewed } \\
\text { as too complex to be useful. }\end{array}$ & $\begin{array}{l}\text { - Eating here: Greater Philadelphia's food system } \\
\text { plan. Pennsylvania. (DVRPC, 2011) } \\
\text { - Food system assessment for Oakland: Towards a } \\
\text { sustainable food plan. California. (Unger \& } \\
\text { Wooten, 2006) } \\
\text { - The new mainstream: A sustainable food agenda } \\
\text { for California. California. (Brady, 2005) } \\
\text { - Farm to plate initiative. Vermont. (Vermont } \\
\text { Sustainable Jobs Fund, 2011) } \\
\text { - Local Food Assessment and Plan. Ohio. (Mid- } \\
\text { Ohio Regional Planning Commission, 2010) } \\
\text { - Ohio's food systems: Farms at the heart of it all. } \\
\text { Ohio. (Meter, 2011b) }\end{array}$ \\
\hline $\begin{array}{l}\text { Community Food } \\
\text { Securitya Assessment }\end{array}$ & $\begin{array}{l}\text { Engage community } \\
\text { members in assessing } \\
\text { food system access and } \\
\text { framing action initia- } \\
\text { tives. Improve low- } \\
\text { income food access and } \\
\text { participation; promote } \\
\text { food security. Identify } \\
\text { key system dynamics } \\
\text { affecting low-income }\end{array}$ & $\begin{array}{l}\text { Compile demographic } \\
\text { data; prepare narra- } \\
\text { tives, lists, or maps } \\
\text { showing food access } \\
\text { concerns of low-income } \\
\text { residents; identify } \\
\text { placement of groceries } \\
\text { or farm stands; assess } \\
\text { adequacy of food } \\
\text { supply; identify logistical }\end{array}$ & $\begin{array}{l}\text { - It may be difficult to convince } \\
\text { local decision makers that } \\
\text { ensuring access to low-income } \\
\text { consumers is an essential part of } \\
\text { a food assessment. } \\
\text { - Unless researchers are savvy } \\
\text { about working with low-income } \\
\text { constituencies, tensions may } \\
\text { develop between residents and } \\
\text { research staff. }\end{array}$ & $\begin{array}{l}\text { - Making room at the table: A guide to community } \\
\text { food security in Connecticut. Connecticut. } \\
\text { (Connecticut Food Policy Council, 1998) } \\
\text { - Bedford-Stuyvesant community food } \\
\text { assessment. New York. (City Harvest, 2010) } \\
\text { - Burlington community food assessment. } \\
\text { Vermont. (Burlington Food Council, 2004) } \\
\text { - From Our Own Soil: A Community Food } \\
\text { Assessment, Benton County Oregon and its } \\
\text { Foodshed. Oregon. (Ecumenical Ministries of }\end{array}$ \\
\hline
\end{tabular}




\begin{tabular}{|c|c|c|c|c|}
\hline Assessment Type & Purposes & Methodologies & Limitations & Selected Examples \\
\hline & residents. & $\begin{array}{l}\text { barriers that tend to } \\
\text { exclude low-income } \\
\text { residents; identify } \\
\text { cultural traditions and } \\
\text { concerns. Qualitative } \\
\text { analysis of focus } \\
\text { groups, surveys and } \\
\text { interviews with food } \\
\text { system stakeholders. }\end{array}$ & $\begin{array}{l}\text { - If the assessment focuses too } \\
\text { narrowly on low-income } \\
\text { communities, it may miss } \\
\text { potential external resources. }\end{array}$ & $\begin{array}{l}\text { Oregon, 2006) } \\
\text { - La Plata County food assessment. Durango, } \\
\text { Colo.: Growing Partners of Southwest Colorado. } \\
\text { Colorado. (Growing Partners of Southwest } \\
\text { Colorado, Fitzgerald \& Pepinsky, 2007) }\end{array}$ \\
\hline $\begin{array}{l}\text { Community Food } \\
\text { Asset Mapping }\end{array}$ & $\begin{array}{l}\text { Engage residents in } \\
\text { informal mapping } \\
\text { exercise to take asset- } \\
\text { based approach to food- } \\
\text { system visioning. }\end{array}$ & $\begin{array}{l}\text { Participatory mapping } \\
\text { or listing exercises to } \\
\text { identify existing or } \\
\text { potential community } \\
\text { food assets. }\end{array}$ & $\begin{array}{l}\text { - Informality may inhibit compre- } \\
\text { hensive evaluation or dissemi- } \\
\text { nation. } \\
\text { - Unless researchers are savvy in } \\
\text { building capacity in low-income } \\
\text { communities, tensions may } \\
\text { develop between residents and } \\
\text { professional staff. }\end{array}$ & $\begin{array}{l}\text { - Analyzing local food systems for success: } \\
\text { Naming and graphing entrepreneurial and } \\
\text { community based agriculture linkages. lowa. } \\
\text { (Smith, Huber, \& Russell, 2007) }\end{array}$ \\
\hline $\begin{array}{l}\text { Food Desert } \\
\text { Assessment }\end{array}$ & $\begin{array}{l}\text { Identify locations in a } \\
\text { given region where } \\
\text { residents have limited } \\
\text { access to supermarkets } \\
\text { or other healthy food } \\
\text { sources. Identify resi- } \\
\text { dent concerns about } \\
\text { food access. }\end{array}$ & $\begin{array}{l}\text { Geospatial analysis of } \\
\text { food stores' proximity to } \\
\text { residential neighbor- } \\
\text { hoods; qualitative } \\
\text { analysis of resident } \\
\text { perceptions of access } \\
\text { and health issues. }\end{array}$ & $\begin{array}{l}\text { - The term "food desert" is often } \\
\text { viewed as offensive to low- } \\
\text { income communities. } \\
\text { - A focus on what a community } \\
\text { lacks, rather than what } \\
\text { resources it has, can have } \\
\text { negative psychological impacts } \\
\text { on the community. } \\
\text { - The concept of "food desert" } \\
\text { focuses primarily on access to } \\
\text { grocery stores, neglecting } \\
\text { smaller food retailers and } \\
\text { community food production. }\end{array}$ & $\begin{array}{l}\text { - Access to affordable and nutritious food - } \\
\text { measuring and understanding food deserts and } \\
\text { their consequences: Report to Congress. United } \\
\text { States. (Ver Ploeg et al., 2009) } \\
\text { - Examining the impact of food deserts on public } \\
\text { health in Chicago. Illinois. (Mari Gallagher } \\
\text { Research \& Consulting Group, 2006) }\end{array}$ \\
\hline $\begin{array}{l}\text { Land Inventory Food } \\
\text { Assessment }\end{array}$ & $\begin{array}{l}\text { Identify underutilized } \\
\text { land suitable for agri- } \\
\text { culture and assess the } \\
\text { extent to which a } \\
\text { municipality or region } \\
\text { can feed itself. }\end{array}$ & $\begin{array}{l}\text { GIS mapping of under- } \\
\text { utilized land, soils data, } \\
\text { water access, and } \\
\text { collection of other } \\
\text { information useful to } \\
\text { urban agriculture. }\end{array}$ & $\begin{array}{l}\text { - Assessments tend to rely on } \\
\text { technology rather than engaging } \\
\text { community residents and } \\
\text { farmers in the study process. } \\
\text { - Other key elements of the } \\
\text { region's food processing, stor- } \\
\text { age, and distribution capacities } \\
\text { generally are not included }\end{array}$ & $\begin{array}{l}\text { - Cultivating the commons: An assessment of the } \\
\text { potential for urban agriculture on Oakland's } \\
\text { public land. California. (McClintock \& Cooper, } \\
\text { 2010) } \\
\text { - The diggable city: Making urban agriculture a } \\
\text { planning priority. Oregon. (Balmer et al., 2006) }\end{array}$ \\
\hline
\end{tabular}




\begin{tabular}{|c|c|c|c|c|}
\hline Assessment Type & Purposes & Methodologies & Limitations & Selected Examples \\
\hline $\begin{array}{l}\text { Local Food Economy } \\
\text { Assessment }\end{array}$ & $\begin{array}{l}\text { Assess prevailing } \\
\text { economic conditions in } \\
\text { local farm and food } \\
\text { systems. Make the case } \\
\text { for community-based } \\
\text { food commerce, jobs } \\
\text { and wealth creation; } \\
\text { unify local stakeholders } \\
\text { around economic } \\
\text { analysis of food system; } \\
\text { help engage local } \\
\text { officials in food } \\
\text { planning. }\end{array}$ & $\begin{array}{l}\text { Compile and analyze } \\
\text { demographic and } \\
\text { economic data, identify } \\
\text { historical trends, } \\
\text { identify current or } \\
\text { potential business } \\
\text { clusters, calculate } \\
\text { economic multipliers. }\end{array}$ & $\begin{array}{l}\text { - Often overlook key elements of } \\
\text { social and environmental } \\
\text { sustainability. } \\
\text { - Given global economic forces, it } \\
\text { may be difficult for a localized } \\
\text { view of economics to be } \\
\text { persuasive. } \\
\text { - Prevailing economic constructs } \\
\text { may not effectively encompass } \\
\text { local foods and economies. }\end{array}$ & $\begin{array}{l}\text { - Finding food in farm country. Minnesota. (Meter } \\
\text { \& Rosales, 2001) (Also } 70 \text { related studies in } 30 \\
\text { states, www.crcworks.org/?submit=fffc) } \\
\text { - The food system as an economic driver: } \\
\text { Strategies and applications for Michigan. } \\
\text { Michigan. (Conner, Knudson, Hamm, \& Peterson, } \\
\text { 2008) } \\
\text { - The 25\% shift: The benefits of food localization } \\
\text { for Northeast Ohio \& how to realize them. Ohio. } \\
\text { (Masi, Schaller, \& Shuman, 2010) } \\
\text { - Economic impact summaries for local food } \\
\text { production. lowa. (Swenson, 2007) } \\
\text { - Ohio's food systems: farms at the heart of it all. } \\
\text { Ohio. (Meter, 2011b) }\end{array}$ \\
\hline $\begin{array}{l}\text { Food Industry } \\
\text { Assessment }\end{array}$ & $\begin{array}{l}\text { Identify key food } \\
\text { industries in a region, } \\
\text { perhaps assist investors } \\
\text { in making investment } \\
\text { decisions, or identify } \\
\text { existing or potential } \\
\text { industry clusters in } \\
\text { food. }\end{array}$ & $\begin{array}{l}\text { Compile quantitative } \\
\text { data covering local food } \\
\text { businesses or clusters } \\
\text { of related firms. }\end{array}$ & $\begin{array}{l}\text { - May overlook key elements of } \\
\text { social and environmental } \\
\text { sustainability. } \\
\text { - May be systematic in scope } \\
\text { methodically, without paying } \\
\text { close attention to system } \\
\text { dynamics. }\end{array}$ & $\begin{array}{l}\text { - Mapping the Minnesota food industry. } \\
\text { Minnesota. (Meter, 2009) } \\
\text { - The competitive advantage of the inner city. } \\
\text { United States. (Porter, 1995) } \\
\text { - Agricultural and food industry clusters in the } \\
\text { Northeast US. United States. (Goetz, Shields, \& } \\
\text { Wang, 2004) } \\
\text { - Toronto's key industry clusters: Food \& beverage. } \\
\text { Ontario. (Wolfson, 2010) }\end{array}$ \\
\hline
\end{tabular}

Note. This table was created by Marisol Pierce-Quiñonez and Ken Meter. Select elements of this table were presented by Ken Meter as part of a webinar offered for the Centers for Disease Control (Meter, K. (2011). Using food system assessments with food policy councils. May 16. http://www.crcworks.org/crcppts/KMcdc11.pdf). All studies have full citations in the references section.

a The Community Food Security Coalition (CFSC) defines food security as "increasing access to food and the active participation of low-income residents in creating a more responsive food system." 
galvanized community desire to localize food supplies because it opens the door to the development of a modern food system that simultaneously supports local and regional agriculture and the dietary needs of people in nearby population centers. Chris Peters, originally of Cornell University, has led the academic work on foodshed assessments. Beginning with 2003 papers that explored the relationship between local agricultural production and nutrition (Peters, Bills, Wilkins, \& Smith, 2003a, 2003b), Cornell researchers have published a series of foodshed studies that measure the land resource requirements of food production in New York. A 2007 paper tested a complete diet framework to understand how diet influences the demand for agricultural land (Peters, Wilkins, \& Fick, 2007). In this paper, researchers called for a geospatial framework to improve understanding of the ability of a local region to supply more of its own food. This led to a paper on mapping potential foodsheds in New York that provides a template for considering the geography of food production and consumption simultaneously (Peters, Bills, Lembo, Wilkins, \& Fick, 2009).

Most recently, Cornell released a Local Foodshed Mapping Tool that establishes the productive capacity of agricultural land by geospatially analyzing soils data, land use, and production averages from the U.S. Census of Agriculture (Cornell University Cooperative Extension, 2011). What began as Peters' master's thesis, aimed at linking food production and consumption, has evolved into a sophisticated web-based tool which is currently live for the state of New York, with plans to bring data for the rest of the country online by fall 2011.

The Local Foodshed Mapping Tool allows users to visualize the geographic area required to feed population centers within the state, based on the productive capacity of local farmland and optimization modeling techniques that minimize the number of food miles from production to consumption. The tool will be very useful to planners who want to assess the capacity of local agriculture to feed communities within its foodshed. However, unlike assessments that address the entire system, it does not take into consideration processing facili- ties or distribution networks needed to turn the capacity into a practical reality. Another limitation of this approach is that many practitioners assume each parcel of land will support only a single commodity, when in fact many farmers rotate through a variety of crops and livestock, leaving land fallow as well.

In 2008, American Farmland Trust (AFT) released Think Globally, Eat Locally: San Francisco Foodshed Assessment, attempting to answer the question, "could the City of San Francisco feed itself with local food from farms and ranches within 100 miles $[160 \mathrm{~km}]$ of the Golden Gate Bridge?” (Thompson, Harper, \& Kraus, 2008, p. 1). Using a 100-mile radius as a proxy, the study examined to what extent people in the Bay Area could improve their well-being and reduce their global footprint by eating locally. The report documents both the answers that AFT found and the additional questions that arose because of the investigation.

The agricultural data available were ample for conducting an analysis. The study found that more than 80 different commodities were produced in the foodshed, only a handful of which lacked the abundance to satisfy the food requirements of the city and Bay Area. However, the assessment was limited by deficiencies in consumer data available to trace the flow of food from producer to consumer. It was not possible to determine accurately how much food grown within the foodshed actually was consumed in the city or how much of what was consumed in the city was produced by local farms and ranches. Beyond the fact that private enterprises withhold privileged information, decades of modernization to achieve convenience, consolidation and standardization has made it impossible to trace the what, when, where, who, and how of where our food comes from. Thus, among other recommendations, the report calls for expansion of local infrastructure to store, process, preserve, and transport local food, but does not propose the means by which to achieve this.

\section{Land Inventory Food Assessment}

Land inventories are essentially a subset of foodshed assessments. They identify property charac- 
teristics that may shape the future potential for food system creation, and are used particularly by people working to build urban or regional agricultural systems. The inventory process might include: (1) listing underutilized parcels of land, (2) identifying how much land would be needed to feed a given population, and/or (3) identifying lands in a region that are especially suited (or not) to producing food or supporting agriculture. Often the inventories are overlaid with maps showing characteristics such as soil quality, slope, and water access, to determine whether a given area is suitable for cultivation. Assessments then combine this supply-side data with consumption data to determine the potential contribution agriculture can make to the total food needs of a city or region. Land inventories do not necessarily address the political feasibility of converting all available land to agricultural use, nor do they address the additional infrastructure required by such a change to local land use.

A land inventory for the city of Oakland found that $5 \%$ to $10 \%$ of the city's food needs could come from within city boundaries (McClintock \& Cooper, 2009), while a similar study in Toronto found that through community gardens, existing small farms, green roofs, and institutional lands, roughly $10 \%$ of Toronto's food needs could be met (MacRae et al., 2010). Like other foodshed models, these inventories do not take into account what it takes to connect the food that could be grown on this land to consumers. In addition, they do not address the limited number of people with sufficient access to capital and land, and who have the desire and drive to commercially produce and market farm products.

\section{Comprehensive Food System Assessments} Among the many tools people engaged in planning can use to promote sustainability is drawing upon environmental information to guide policy through the use of sustainability indicators. While few sets of sustainability indicators have made dramatic impacts on policy or governmental operations, municipalities such as the city of Santa Monica have begun to tie budget decisions to agency achievement of sustainability goals, and linked indicators have helped show interconnections among systemic issues (Meter, 2004, 2007). ${ }^{2}$ Another tool is to assess the environmental effects of policies through environmental impact assessments (Levett, 1997).

Food system assessments (FSAs) are a promising new combination of these and other assessment tools. Some FSAs are used to gather information, some are launched as part of a process of engaging citizens in visioning or planning processes, some are aimed at understanding prevailing economic conditions or food system dynamics, while others are used to measure the changes in various system parameters over time. FSAs are meant to operate through a systems framework in which individual disciplines are viewed as interconnected fields instead of separate domains. Research aims go beyond the productive capacity of a given region ultimately to address the entire life cycle of the food and farming system. Thus FSAs encompass the complex relationships within a food system, starting with stewardship of land and water resources and the cultivation of crops and livestock, moving through the supply chain ${ }^{3}$ to the acquisition and consumption of food, and completing the cycle with the disposal and reuse of agricultural and food-product waste.

Food system assessments are more comprehensive in scope than foodshed assessments. Where foodshed assessments focus on the connection between the availability and capacity of agriculture and the land base to support food and dietary needs, food system assessments address more of the social and economic factors involved in getting food from farm to fork (Curtis, Creamer, \& Thraves, 2010). They may also include close attention to environmental concerns, and the linkages among sustainability issues. Since the food system is more than just production outputs and consumption statistics, FSAs assess food access and often address the hardships associated with bringing food to marginalized communities. These assessments recognize

\footnotetext{
2 http://www.smgov.net/departments/ose/

${ }^{3}$ Sometimes referred to as "value networks." See Meter, K., JAFSCD, 2(1), "Breaking Our Chains."
} 
that a food system will result in hunger unless it is just and equitable, and it includes policies that promote food access and distribution.

FSAs are also part of an emerging field focused on the evaluation of systems. Systemic evaluation involves looking at the "big picture," but also analyzing the interconnections between pieces of that picture (Williams \& Imam, 2007). Food systems are complex adaptive systems. How researchers define the boundaries of a given system and investigate its relationship to other systems can markedly affect results. Meter (2007) discusses the use of several system frameworks in evaluating food systems, finding that, although complicated, systemic frameworks can provide valuable insights into the workings of food systems. Meter views food systems as "complex adaptive systems" (p. 153) in which the essential dynamics of the system change over time. As such, using specified quantitative indicators may be tricky; key indicators may wax and wane in importance over time. Thus, his research integrates time-series data and other quantitative measures with qualitative comments from "wise practitioners" with practical experience in the food system. Often these practitioners, being embedded in community contexts, hold deep insight about systems dynamics that are difficult for specialists to see on their own.

Often a FSA and a food system plan are released as a single document. Such is the case for the Food System Assessment for Oakland: Towards a Sustainable Food Plan (Unger \& Wooten, 2006) and the Assessment and Action Plan for Localization in $W$ ashtenaw County, Michigan (Davis et al., 2004). Since food systems are not truly sustainable if they do not ensure food security, food access is a central point of focus for these reports, as with community food assessments. However, addressing the complexity of local/regional food systems is their chief purpose. Therefore, they typically recommend ways to improve every aspect of the system, including the production, processing, packing, distribution, acquisition, and disposal and reuse of food and food and agricultural waste.
The priorities embedded in sustainable local, state and regional food systems often conflict with one another, resulting in a complex web of food policy priorities. An FSA can help elucidate priorities, using existing data and stakeholder input as a guide. Input from the community at large is important, but not necessarily an intrinsic part of an FSA, as reports can be developed by mining the data collected by government institutions such as the USDA, the Bureau of Labor Statistics, and the U.S. Census, as well as local planning and health departments.

FSAs are conducted by local and regional governments, coalitions of food and farming organizations, food policy councils, consultants, and academics. Unlike CFAs, no standard toolkit has been developed to support them, so reports and outcomes are difficult to compare. Often this has led to an incomplete picture of the complexity of the overlapping issues that should be addressed. For instance, A Healthy Seasonal Local Food System Plan for Linn \& Johnson Counties in Iowa prioritizes the economic viability of local farms, but does not address the environmental impacts of agriculture such as soil erosion and water pollution (Linn/Johnson Local Food Task Force, 2010).

Taking FSAs a step further toward planning, the Sacramento Area Council of Governments (SACOG) assessed the potential to develop regional food infrastructure for its six-county planning area, which includes the city of Sacramento and surrounding rural communities. Following the adoption of its Blueprint 50-Year Smart Growth Land-Use Strategy, SACOG initiated a RuralUrban Connections Strategy (RUCS) to address agricultural conservation and infrastructure, among other issues. It used a web-based platform called IPLACE3S, which supports scenario planning, to develop a sophisticated, data-driven tool to analyze a range of situations and test multiple variables and economic indicators (SACOG, 2009). One of the things this achieved was the ability to assess the relationship between market conditions, land use changes, and demand on resources such as water, labor, and transportation and infrastructure. 
(National Association of Development Organizations Research Foundation, 2011)

At the end of the 2009 session, the Vermont legislature approved the Vermont Farm to Plate (F2P) Initiative. After extensive research, community outreach, and planning, in 2011 F2P released a 10year strategic plan to strengthen the state's food system (Vermont Sustainable Jobs Fund, 2011). Led by the Vermont Sustainable Jobs Fund in consultation with the Sustainable Agriculture Council and other stakeholders, this soil-to-soil analysis is rich with data that starts with examining agricultural inputs, follows agricultural products through processing and market distribution, and ends with an analysis of what happens to these products when they are returned to the environment. F2P is one of the most comprehensive food system assessments in circulation.

The Vermont F2P Initiative is a good example of a food system assessment and a strategic plan that resulted from an extensive stakeholder process. The F2P explored current conditions, assessed barriers and gaps, identified emerging opportunities, and provided a series of objectives and strategies including a market-oriented Farm and Food Enterprise Development Framework. Addressing the question of whether Vermonters can feed themselves through local food production, as with foodshed assessments, the analysis concluded, "no comprehensive data exist to indicate exactly how much and what type of food - local or imported - is currently being consumed by Vermonters" (Vermont Sustainable Jobs Fund, 2011, p. 12). ${ }^{4}$ However, the project has an entire section on goals, indicators, and measures to strengthen the state's agricultural sector and reconnect food production and consumption, not only among households but in schools and other institutions as well.

Of the various organizations that are responsible for FSAs, Regional Planning Organizations (RPOs) and Metropolitan Planning Organizations (MPOs) hold great promise for conducting assessments that

\footnotetext{
${ }^{4}$ A follow-up study has been commissioned to begin this measurement process.
}

will lead to plans and policies strengthening local, state, and regional food systems, because planners are trained to take a systems approach to problem solving. Planners are familiar with many of the ideas associated with food system assessments, such as the needs of low-income residents, the primacy of sustainability, the community as a unit of analysis, and the interdisciplinary nature of the topic (Pothukuchi, 2004). The commonalities between food systems and the planning profession make planners well suited to prepare as well as to use FSAs.

The Delaware River Valley Planning Commission (DVRPC) is a case in point. Beginning in 2009, the Philadelphia-based MPO conducted a food system study specifically to lay groundwork for a food systems plan (DVRPC, 2011). Using planners' skills to bring multiple, diverse stakeholders together and with all assessment tools at their disposal, DVRPC developed baseline conditions for the region's foodshed as a precursor to developing its regional food system plan. It identified characteristics of the foodshed, used the USDA Census of Agriculture to examine agricultural conditions and the farmland base needed to sustain food and farming in the region, and mapped remaining agricultural soils.

Similar to the AFT foodshed study, DVRPC used a theoretical geographical area - a 100-mile (160$\mathrm{km}$ ) radius from Philadelphia — to designate the Greater Philadelphia regional foodshed. Using the foodprint methodology (Peters et al., 2009), DVRPC determined that Philadelphia's 5.5 million people needed 6.8 million acres of agricultural land to meet their annual nutritional needs. This would require 2.8 million more acres of land than is encompassed in its foodshed.

Further calculations comparing the total value of agricultural products sold in the region and the amount of food purchased in Greater Philadelphia illustrated the gap between production and consumption: a total of US $\$ 6$ billion of agricultural products were sold in 2007, including food, while consumers in Greater Philadelphia purchased US $\$ 15$ billion of food. While DVRPC found it 
difficult to trace the origin of most of the food consumed in the region, it was able to determine that the region consumes most of what it grows, estimating that $61 \%$ of all food freight shipments originating in the region were destined for purchase within the region.

Based on their FSA and the multiyear stakeholderdriven process, in February 2011 DVRPC released Eating Here: Greater Philadelphia's Food System Plan, one of the most comprehensive food system plans to date. Eating Here details more than 50 recommendations for strengthening the regional economy and agricultural sector, decreasing waste and want, enhancing public health, protecting soil and water, and encouraging diversity, innovation and collaboration. These recommendations can be measured using a set of 10 indicators.

As an example of another MPO, the Mid-Ohio Regional Planning Commission (MORPC) released the Central Obio Local Food Assessment and Plan in 2010, which contains five goal categories: Increase the Supply of Local Food, Expand the Local Food Infrastructure, Improve the Viability of Farm and Food Businesses, Remove Barriers to a Local-Food System, and Increase Understanding of Local Food and its Benefits. These goals support 13 short-term recommendations and 11 long-term recommendations to "build a regional food system that can make farms more viable...promote healthful eating and living; strengthen rural and urban communities that grow and process food; and create a resilient network of farms and food-related businesses" (MORPC, 2010, p. 31). Based on the work of five task forces within their Agriculture and Food Systems Working Group, MORPC engaged 80 individuals, representing a variety of interests throughout the region's 12 counties, to guide and conduct the assessment.

Another assessment of Ohio's food systems (Meter, 2011b) found that US $\$ 30$ billion drains from Ohio food systems each year through three channels: (a) farmers gain only a small amount by producing commodities for export, yet (b) buy billions of dollars of essential inputs sourced outside the state, while (c) consumers eat food that is grown outside Ohio (Meter, 2011b). The study argued that recapturing these dollars would create significant economic opportunities, and touched on a variety of related issues: from historical trends that have created an emphasis on export-based commercial infrastructure, to the vulnerability inherent in reliance on fossil fuels, to the medical costs of treating diabetes and related conditions. Further, it identified food-related firms that have been building clustered business relationships for more than 40 years and proposed public and private investment to strengthen this ongoing business development. The growth of these business networks over four decades was analyzed as a dynamic of systemic emergence.

\section{Community Food Security Assessments}

A community food security assessment (CFSA) is a community-based approach to measuring, envisioning, and/or creating a more secure and just food system. CFSAs are produced by community members, often but not always with the assistance of technical experts, and designed to address local conditions. Usually, because of the leadership of the Community Food Security Coalition (CFSC), which has emphasized food security, CFSAs have prioritized work in low-income neighborhoods. Some emphasize access to food, while others involve a more integrated picture of the food system that includes production, distribution, and recycling of food waste.

Hundreds of CFSAs have been conducted across the country. The CFSC toolkit uses a slightly different term, community food assessment (CFA), defining CFA as a "collaborative and participatory process that systematically examines a broad range of community food issues and assets, so as to inform change actions to make the community more food secure" (Pothukuchi, Joseph, Burton, \& Fisher, 2002, p. 11). ${ }^{5}$ CFSC notes that the goal of a CFA is often broader than measurement or practical recommendations; often, the focus is on

\footnotetext{
${ }^{5}$ CFSC defines food security as increasing access to food and the active participation of low-income residents in creating a more responsive food system.
} 
gathering data, civic engagement and coalitionbuilding.

The Bedford-Stuyvesant community food assessment of New York City is an interesting example of a CFA. City Harvest conducted the assessment in collaboration with 17 local food and agriculture organizations, obtaining data from community members surveyed in several subway stations and churches in the Bedford-Stuyvesant neighborhood of Brooklyn (City Harvest, 2010). The assessment gathered information on the demographic makeup of the community and secondary data from a variety of food- and hunger-related studies conducted in the past. Primary research was conducted to assess current food needs. Interviews, surveys, and focus groups aimed at answering questions about food access, affordability, and quality, and subjects' personal eating habits. Additional information on the retail food environment was gathered by visiting grocery stores and conducting price comparisons and qualitative assessments of the freshness and appearance of food items. Six recommendations for community-based food policy changes were made.

\section{Community Food Asset Mapping}

One relatively simple exercise that is used by citizen food planners and also by professional planners to convene a food planning process is to map local food system assets. Often a highly energizing step for a community to take, this can be effectively used to set a positive tone at the launch of a public process. Avoiding the negative implications of a "needs" assessment (which can spiral community members into inactivity), an "asset map" can bring people together more positively to discuss what their community already has, rather than what it lacks. Residents often build a strong spirit of collaboration by enjoying new discoveries and capacities together. Using imagery rather than words may enhance the participation of people who often feel marginalized by more formal processes. One hourlong session can at times launch several months' worth of activity, so this can be a deeply effective way to energize a civic planning process.

A food asset map can be done as an exercise of drawing an informal map on butcher paper, or it can be performed using a sophisticated GIS platform. It can be as simple as making a word list of current or potential food system assets, or it can produce a well developed study document. Professionals and civic leaders can work on the map together, or low-income residents can collaborate to form a new appreciation of what their community already owns and what local practitioners have already accomplished. One author of this paper has used asset mapping to identify vacant buildings that were viewed as eyesores, but which became valued as potential locations for future food system activity. If led by a practitioner having a solid grasp of systemic work, residents will often identify essential system dynamics as they discuss what their work circle has placed on the map.

A pioneer in developing food asset mapping has been Carol Richardson Smith, who worked extensively with communities across Iowa in her former position with the National Catholic Rural Life Conference (Smith, Huber, \& Russell, 2007). Asset-based planning processes have also been advanced by the Asset-Based Community Development practitioners at Northwestern University (Asset-Based Community Development Institute, 2009). Yet the very nature of this work - it is relatively easy to do spontaneously, and lends itself well to informal settings - limits the production of formal papers, or the scholarly treatment of this as a formal methodology. This approach may be one part of a CFSA process, but does not inherently engage low-income residents or treat food security concerns. Because of its focus on land and facilities, an asset-mapping exercise tends to move rapidly to coverage of distribution and other infrastructure; it also lends itself well to expanding into a discussion about existing or potential local food businesses, and may help to identify local business clusters. Asset-mapping can also be an excellent technique for drawing out resident wisdom in identifying patterns of emergence ${ }^{6}$ in local food systems.

\footnotetext{
${ }^{6}$ For a definition of patterns of emergence, see Williams \& Imam (2007), pages 134-135.
} 


\section{Food Desert Assessment}

A "food desert" is defined as a geographical area that lacks adequate access to affordable and healthy food (Cummins \& Macintyre, 2002). Defining access is a complicated task: it can mean anything from lack of healthy produce at local corner stores to the absence of full-service supermarkets within walking or driving distance from a population. The Mari Gallagher Research and Consulting firm produced several groundbreaking food desert assessments, defining a food desert as a "large geographic area with no or distant grocery stores" (Gallagher, 2006, p. 6). Food desert assessments have been valuable tools in calling attention to the lack of adequate access to healthy foods through graphical representation of the issue through maps. Although the term has evoked broad interest and is easy to comprehend, it has not always been welcomed by low-income residents themselves.

In 2009 the USDA released a report on U.S. food access, which mapped supermarkets and other large grocery stores and classified geographic areas as low-, medium-, or high-access areas (Ver Ploeg et al., 2009). In 2011 the data was brought online to create an interactive map in conjunction with the Let's Move! Campaign (USDA, 2011). It is meant to be an informational tool and also as a guide for food retail development through the Healthy Food Finance Initiative (HFFI).

Food deserts have been associated primarily with low-income urban areas, but researchers have found that inadequate access exists in rural communities as well (Meter \& Rosales, 2001). A metaanalysis of food access studies conducted by Policy Link and the Food Trust compiled a comprehensive bibliography from the past 20 years that profiled 132 studies: 61 published in peer-reviewed journals primarily conducted by university-based researchers, and 71 conducted and self-published by practitioners or policy researchers that were sometimes completed in collaboration with academic researchers (Treuhaft \& Karpyn, 2010). It found that accessing healthy food is particularly challenging for "those living in low-income neighborhoods, communities of color, and rural areas" (p. 13). The report notes that the majority of studies focus on urban areas, but 20 studies found significant food access issues in rural communities. The study concluded that rural areas can suffer from severe distances between retailers, and often see a decline in small food retailers due to the rise of supercenters.

Despite the widespread adoption of the term "food desert" and the local and federal programs based around various definitions, some communities reject the term. The term can be construed as overly negative in its focus on a quality that the neighborhood lacks rather than on its current or potential assets. Others take issue with the importance placed on supermarkets, and argue that smaller corner stores and bodegas should also be taken into consideration when qualifying food access. Still another critique is not about the term itself, but rather about the emphasis this conceptual approach places on food consumption rather than production. Many food security leaders insist it is more important to build resident capacity to produce and process foods for their own community, rather than simply ensuring grocery store access; in a rural context, this often suggests a goal of ensuring that farmers produce more foods that can support the family itself, or are sold directly to consumers, rather than through grocers.

\section{Local Food Economy Assessments}

Other food assessments review the prevailing economic trends in food and agriculture with an eye toward strengthening the local economy by creating clusters of local foods businesses and supportive infrastructure. This analysis may be a standalone economic study, or an element of a broader CFA or food-system assessment. Local economic assessments often make the case that a food system that promotes the purchase of locally produced foods keeps more money within the local economy, thus creating a more prosperous locale or region.

A variety of economic assessments have been conducted across the country, in both urban and rural settings. Since money is the vehicle society uses to place value on competing uses of resources (for example, whether it is more valuable to compost 
organic matter to build soil fertility, or to apply chemical fertilizers), economic analysis constantly crosses disciplinary lines. This makes economics a powerful lens for integrative work by planners. For example, a 2008 Michigan State University inputoutput analysis found that transitioning to a more local, sustainable food system in Michigan would create about 2,000 Michigan jobs and US $\$ 200$ million in new labor income (Conner, Knudson, Hamm, \& Peterson, 2008).

Calculations of economic multipliers also play a key role in planning decisions, since investment choices often hinge on the extent to which jobs and labor income are anticipated from a proposed project or plan. For example, an Iowa economist found that a small restaurant that had committed itself to buying local foods generated a multiplier of 1.9 in an eight-county area, as compared to a value of 1.5 for an average restaurant in the region (Swenson, 2007). Another study found that a rural economy in western Wisconsin, based on small farms, generated an overall output multiplier of between 2.2 and 2.6 (Swain, 1999; L. B. Swain, personal interview, February 12, 2001; Swain \& Kabes, 1998).

Essentially, economic multipliers measure how a specific business or sector interacts with the prevailing infrastructure (Meter, 2010). Often the net impact of local food investments is relatively small compared to the prevailing economy, so the most successful practitioners insert new functions into the software to ask questions that have meaningful answers. As one example, since the amount of food traded in one Iowa region was too small to show a marked difference in IMPLAN, ${ }^{7}$ researchers calculated the difference in multipliers for two restaurants, one of which purchased foods locally (Swenson, 2007). Higher multipliers are also, in general, a sign of stronger social connectivity, i.e., social capital. When interpreting a multiplier study, it is important to ask whether the definition of "local" used is simply taken to mean purchased

${ }^{7}$ IMPLAN is software system for local-level economic impact analysis. See more at http://implan.com/V4/Index.php locally, or rather sourced locally. The latter test yields lower, but more realistic, multipliers.

\section{Food Industry Assessments}

Many food analysts limit themselves to an overview of business activity, viewing it as separable from social and environmental concerns. A classic example would be the precise analysis of business dynamics that a stock analyst or financial reporter might produce that illuminates the profitability of an industry or highlights investment trends. Many industry assessments are effective analyses of food systems, but because they often are performed with the assumption that the financial system is the only system worth covering, they are often less comprehensive than other assessment tools. They also tend to be more static in their nature, viewing the financial sector more as a financial mechanism with changes only within predictable realms, and less as a complex adaptive system.

Still, industry assessments can be valuable to both citizen and professional food planners. The Toronto study listed in table 1, for example, highlights food industry clusters in that region. The study could certainly form the basis of concerted planning to strengthen this sector; or work such as this could be expanded into a more complete view of multiple food systems in the region.

Michael Porter's work (1995) has highlighted his contention that inner-city grocery stores often are among the most profitable markets in the United States. This seems to occur primarily when groceries are located at the boundary between lower-income and upper-income neighborhoods, and the stores become cultural meeting grounds where consumers of all strata feel comfortable shopping. This is of clear importance to foodsystem and land-use planning efforts.

Mapping the Minnesota Food Industry (Meter, 2009) is a hybrid: a food industry assessment that is also one of the first efforts to consciously develop a systemic framework for analysis of the food industry. This study also considers the state food system to be a complex adaptive system. The title was specified by the contractor that commissioned 
the study in advance of the writing, but the work also focuses on emergent qualities of the food system, and offers 10 "system levers" that the author claims drive change in Minnesota food systems toward a new paradigm (p. 64). It pays brief attention to food security issues and the health costs of faulty eating. Its analysis combines time-series data with in-depth interviews with "wise practitioners" who have practical experience in the emergent food system (p. 47).

\section{Applicability of Assessments/Analyses}

The purpose of planning is to analyze, guide, and manage change at the community, city, and regional levels. Professional planning is a practice to create fully accessible communities that are healthy, safe places to live and work; promote social, economic, and racial equity; provide jobs close to home, quality education, affordable housing, transportation choices, recreational and cultural opportunities; promote sustainable natural resource management and protection from environmental hazards 8 ; and, increasingly, to ensure access to healthy and affordable food.

Food system planning is emerging as a discipline for planning professionals as well as nonprofit and community organizations. In some cases, food system elements are included in traditional comprehensive plans. Marin County's countywide plan, for example, outlines steps for building a sustainable food system by protecting farmland, encouraging production of local fruits and vegetables, and promoting healthy eating - and in turn markets for local produce (Marin County Community Development Agency, 2007, pp. 4-5). In other cases, planners can play an important role in building sustainable food systems because their job is to enhance the dynamic relationships between the social, ecological, and economic health of communities. Their interdisciplinary training and crosssectoral work responsibilities are well suited to the task. Young planners in particular - both recent graduates and those currently in school - are learning about food systems while they develop

${ }^{8}$ American Planning Association, http://www.planning.org/apaataglance/mission.htm traditional planning skills. As they move into the workforce, they will become leaders in food system planning practice.

To succeed, however, residents, businesses, planners, and food system professionals need reliable assessment tools, which are still in the early stage of development. These tools will help them bring together the diverse interests in the food system to address the complex issues of creating the connectivity and resiliency needed to ensure sustainability across the food system spectrum. This includes the need to address the environmental problems of the food system more coherently, which could be achieved by incorporating data collected in foodshed analyses.

Environmental analysis would add considerably to understanding the food system. For instance, carbon emissions and food transport were often cited in the studies as environmental impacts of the food system, but are difficult to quantify without an accurate picture of where and how food is being grown and through which channels it is transported to market.

Certainly, all food system assessments draw upon reliable public data sources; it may be possible to devise standard approaches, which help to direct the design and collection of local data. This also could relieve much of the burden of data collection, enabling more time for data analysis and recommendations. Yet each community also has unique challenges and conditions, and adaptive food systems experience emergent change; standardization can only be the beginning of investigation into a community's food system.

Finally, while it is clear that planners have an emerging role to play, there also is a need for them to coordinate and collaborate with people who have experience in sustainable agriculture as well as community food system stakeholders. The vision of the MORPC local food assessment and plan was to make fresh, safe, healthy, and affordable local foods easily and equally accessible in Central Ohio and distributed through a system that promotes sustainable farming practices and resilience in the 
region. To achieve this, the MORPC convened a multicounty agriculture and food systems working group that included professionals spanning the entirety of the food system and that examined production, processing, distribution, and consumption of food throughout the region. The Vermont Sustainable Jobs Fund engaged a broad group to develop the F2P plan, and the diverse DVRPC stakeholder committee included farmers and antihunger groups and engaged organizations as diverse as land trusts and the Food Trust, Farm Credit, and private foundations, as well as economic development councils. Likewise, sustainable agriculture advocates should seek out opportunities to work with planners and take advantage of the systems-based skill set and tools they have at their disposal.

These nascent efforts lay the groundwork for robust food system planning efforts in the years to come. To be most useful to planners and policy makers, it will be important to fully develop comprehensive assessments that include data and recommendations pertaining to farmland protection and the stewardship of natural resources, through the supply chain between production and consumption, ensuring healthy food access to all citizens, and ending with the proper reuse (composting) or disposal of food and agricultural waste. The combination of new assessment tools and broad community engagement inform an exciting new direction for food system planning practice.

\section{Limitations of Assessments}

The most conspicuous limitation of the entire body of food system assessments is that they tend to focus on fresh produce rather than all the foods that make up the U.S. diet. Few refer to the meat and dairy industries, or to wheat, corn, and other commodities. This is a significant problem, as meat, poultry, eggs and dairy compose a considerable portion of the U.S. diet, and much of the U.S. agricultural economy produces feed crops such as corn and soybeans. Beyond their importance to the U.S. diet, livestock operations can be a major contributor to both water pollution and climate change (Steinfeld, Gerber, Wassenaar, Cassel, Mauricio, \& de Haan, 2006, p. 85). Food system assessments should address the complexities inherent in creating more sustainable food systems and pay more attention to environmental and public health issues.

Overall, many studies focus primarily on access to food and some simply on the agricultural land base needed to support food production, with very few that embrace the whole system, including the supply chain that connects them. The AFT San Francisco study is one exception, although researchers were unable to accurately trace food from farm to plate. Food procurement at the wholesale and retail level is a closely guarded secret, making it nearly impossible to know exactly from where an item actually comes. Meter's food system studies also cover the entire supply web (Meter 2009, 2011b). The U.S. Department of Transportation's Freight Analysis Framework is a good approximation of the transport of food through regions, but reveals little about where foodstuffs ultimately end up (U.S. Department of Transportation, 2011). The DVRPC included this information in its assessment; another that has done so is the International Society for Ecology and Culture (Mamen, Gorelick, Norberg-Hodge, \& Deumling, 2004).

The research and reporting costs tend to be too high for comprehensive assessments. Food system professionals may not use assessment tools or may shun food system planning as an unnecessary step in creating on-the-ground projects. Food systems are not uniform from one jurisdiction to the next, so assessments must be tailored to their individual needs.

Foodshed assessments have other limitations. The foodshed concept is more a metaphor than an actuality, and the geographic region needed to supply a population center often will not fit neatly into jurisdictional interests or analyses. Most foodshed assessment focuses solely on farmland capacity and production, and so may overlook key elements of the region's food processing, storage, and distribution capacities, or social concerns. This is especially true of land inventory assessments, which generally 
overlook key elements of the region's food processing, storage, and distribution capacities.

Furthermore, it may be difficult to fund a truly comprehensive food system assessment, as it requires significant time and resources to conduct a holistic examination of a multifaceted system. While professional planners have an established framework for systems analysis, only recently has the framework been applied to food. Given that many actors engage in food systems assessments, it is important to define conceptual and methodological approaches to "systemic" work, which are not always made explicit. Given the expense and complexity of these assessments, there is a danger of underrepresenting key elements of the food system, whether natural resource management, community economic development, food access or disposal of food and farm-related waste, while representing the system as a whole. Despite their limitations, assessments are useful if they are region-specific and lay a blueprint that can continue to be evaluated as the political landscape changes and the food system progresses.

Scores of community food coalitions across the United States are aware that the marketing channels that link producers and consumers are important and that it is critical to create infrastructure that makes local food trade more efficient, but most coalitions lack resources to make this happen. Several assessments in this study identified the need for a community kitchen to support valueadded food enterprises, or a food hub to aggregate and process food in a centralized location. Those studies that cover economic issues most often address these sectors.

It can be difficult to convince local decisionmakers that ensuring access for low-income consumers is an essential part of a food system assessment. Unless researchers are savvy about building capacity in low-income communities, tensions may develop between residents and professional staff. On the other hand, if the assessment focuses too narrowly on low-income communities, it may miss potential resources that are viewed as external, but which could play a positive role. Focusing on what a community lacks, rather than what resources it has, can have negative psychological impacts, making it harder to actually solve the problems identified by the assessment. Finally, the concept of "food deserts" as used to date focuses primarily on access to grocery stores and supermarkets, neglecting other ways that lowincome people may gain access to food, including producing their own.

As with the other types of assessments, those that focus on the local food economy or food industries may be too narrowly focused on economics, thus overlooking key elements of social and environmental sustainability. These assessments tend to take land use economics for granted without addressing key issues of land availability and price. Also, they share the limitations inherent in foodshed assessments because proprietary data is not available to accurately trace the flow of food from the farm to the consumer. Finally, these studies may be systematic in scope (methodical) without being systemic (paying close attention to system dynamics, including complexity).

\section{Further Research}

Over the years progressive researchers have employed various assessment tools to gain a better understanding of food systems (Feenstra \& Campbell, 1998; Gable, 1981). One remaining gap is access to reliable local food consumption data. Further research is needed to both identify and share improved measurement data about what people in specific places really eat, where their food actually comes from, and how it travels through the food system to get to them.

Community food security and local food economy assessments are the most established assessment tools, but recently foodshed and comprehensive food system assessments in particular have attracted significant interest. Our understanding of these, or any food system assessment, would be greatly enhanced through formal professional evaluation or academic review. Evaluating their approaches to stakeholder involvement would be especially useful. 
Assessments that apply to a community context would benefit from evaluation of the extent and efficacy of community engagement, the assessment's ability to unify stakeholders regarding a common agenda, and the impacts of the related food system work on the community defined. It would also be interesting to know whether comprehensive assessments, which are less rooted in individual communities, effectively address stakeholder engagement and how consistently they address land use, economic, and environmental impacts, not only of existing food systems, but also of the ones they seek to create. Such evaluations could help illuminate whether the choice of differing scopes or methodologies leads to different visions of local or regional food systems, or, more importantly, leads to comprehensive food system plans that could be implemented through better policies - not only at the local level, but state and federal policies, as well.

The strengths of comprehensive food system and community food security assessments lie partially in their ability to incorporate many voices into one vision for the future and to unify stakeholders behind that vision. Other assessments may equally serve these purposes if performed properly. The field would benefit from detached research investigating the extent to which those voices are truly representative of the community and its needs, and how researchers overcame challenges in achieving full community engagement. Moreover, a test for bias should be applied to quantitative assessments that do not engage community members. Does an alleged "neutral" analysis actually take the side of one group of stakeholders relative to another? What impacts do community residents experience when their concerns are not addressed in a formal food assessment? Such questions clearly lend themselves to formal professional evaluation or scholarly research.

As noted earlier, a major limitation of all of these studies is the absence of an environmental analysis in the assessments. It would be valuable to research the attitudes of those behind these studies, to determine why environmental concerns tend to be left out of their investigations. Research on the environmental impacts and externalities of the food system, along with recommendations about how to address these in existing food system assessment tools, would enhance food system planning practice and ensure that it addresses the entire system - not just in ensuring a land base for future food production, but evaluating the complete life cycle of the food system and its impacts on soil and water quality, its carbon footprint, the disposal of food and agricultural waste, and so on.

Overall, these studies attempt to achieve similar goals - the promotion of local, regional and/or sustainable food systems - but use different methods to produce their results. Follow-up evaluations should be conducted to determine the extent to which these assessment tools inform truly comprehensive food system plans, and whether those plans foster real policy achievements, and/or community and programmatic change.

\section{References}

American Planning Association. (2007). Policy guide on community and regional food planning.

Washington, D.C.: Author. Available from http://www.planning.org/policy/guides/ adopted/food.htm

Asset-Based Community Development Institute. (2009). Evanston, Illinois: ABCD, School of Education and Social Policy, Northwestern University. http://www.abcdinstitute.org/

Balmer, K., Gill, J., Kaplinger, H., Miller, J., Peterson, M.,...\& Wall, T. (2006). The diggable city: Making urban agriculture a planning priority. Portland, Oregon: The Diggable City Project Team/Nohad A. Toulan School of Urban Studies and Planning, Portland State University. http://www.diggablecity.org/ dcp finalreport PSU.pdf

Benson, J. F. (2003). Round table: What is the alternative? Impact assessment tools and sustainable planning. Impact Assessment and Project Appraisal, 21(4), 261-280.

Brady, E. (2005). The new mainstream: A sustainable food agenda for California for review by the Roots of Change Council and the Roots of Change Fund. Sacramento, California: The Vivid Picture Project/ Ecotrust. http://www.vividpicture.net/documents/The New Mainstream.pdf 
Burlington Food Council. (2004). Burlington community food assessment: An effort to improve nutrition for schoolaged children and develop a more sustainable food system. Burlington, Vermont: Author. http://www.foodsecurity.org/cfa outsideca.html\# vermont

City Harvest. (2010). Bedford-Stuyvesant community food assessment. New York, New York: Author. http://www.hungercenter.org/wp-content/ uploads/2011/06/Community-FoodAssessment Bed-Stuy-Zahilay.pdf

Clapp, J., Stringer, S. M., \& Manhattan (New York, N.Y.). (2010). FoodNYC: A blueprint for a sustainable food system. New York, New York: Manhattan Borough President's Office.

Colasanti, K. J. A., \& Hamm, M. W. (2010). Assessing the local food supply capacity of Detroit, Michigan. Journal of Agriculture, Food Systems, and Community Development, 1(2), 41-58. http://dx.doi.org/10.5304/jafscd.2010.012.002

Connecticut Food Policy Council. (1998). Making room at the table: A guide to community food security in Connecticut. Hartford, Connecticut: CFPC.

Conner, D. S., Knudson, W. A., Hamm, M. W., \& Peterson, H. C. (2008). The food system as an economic driver: Strategies and applications for Michigan. Journal of Hunger \& Environmental Nutrition, 3(4), 371-383. http://dx.doi.org/10.1080/19320240802528849

Cornell University Cooperative Extension. (2010). Local foodshed mapping tool for New York State. Ithaca, New York: Cornell University Department of Crop and Soil Sciences. http://www.cals.cornell.edu/cals/ css/extension/foodshed-mapping.cfm

Cummins, S., \& Macintyre, S. (2002). "Food deserts": Evidence and assumption in health policy making. British Medical Journal, 325, 436-438. http://dx.doi.org/10.1136/bmj.325.7361.436

Curtis, J., Creamer, N., \& Thraves, T. E. (2010). From farm to fork: A guide to building North Carolina's sustainable local food economy. Raleigh, North Carolina: Center for Environmental Farming Systems.

Davis, G., DiRamio, M., Ellis, E. M., Horigome, K., Katz, L. A., \& Martin-Schwarze, A. (2004). Toward a sustainable food system: Assessment and action plan for localization in Washtenaw County, Michigan (Unpublished master's thesis, University of Michigan). http://www.mendeley.com/ research/towardsustainable-food-system-assessment-action-planlocalization-washtenaw-county-michigan/

Delaware Valley Regional Planning Commission (DVRP). (2011). Eating here: Greater Philadelphia's Food System Plan. Philadelphia, Pennsylvania: Author. http://www.dvrpc.org/reports/10063.pdf

Ecumenical Ministries of Oregon. (2006). From our own soil: A community food assessment, Benton County, Oregon, and its foodshed. Available at http://www.emoregon.org/pdfs/IFFP/ CorvallisFoodAssessmentReport-logo.pdf

Feenstra, G., \& Campbell, D. (1998). Community food systems bibliography. Updated: February 2000. Davis, California: UC SAREP. http://www.sarep.ucdavis.edu/cdpp/cfsbib.htm

Gable, M. (1981). Empty breadbasket? The coming challenge to America's food supply and what we can do about it. Kutztown, Pennsylvania: Rodale Press.

Goetz, S. J., Shields, M., \& Wang, Q. (2004). Agricultural and food industry clusters in the Northeast U.S.: Technical report. Rural development paper no. 26. University Park, Pennsylvania: Northeast Regional Center for Rural Development. http://nercrd.psu.edu/ publications/rdppapers/rdp26.pdf

Growing Partners of Southwest Colorado, Fitzgerald, S., \& Pepinsky, K. (2007). La Plata County food assessment. Durango, Colorado: Author.

Guthman, J., Morris, A. W., \& Allen, P. (2006). Squaring farm security and food security in two types of alternative food institutions. Rural Sociology,71(4), 662-684. http://dx.doi.org/10.1526/003601106781262034

Kloppenburg, J., Hendrickson, J., \& Stevenson, G. W. (1996). Coming in to the foodshed. Agriculture and Human Values, 13(3), 33-42. http://dx.doi.org/10.1007/BF01538225

Levett, R. (1997). Tools, techniques and processes for municipal environmental management. Local Environment, 2(2), 189-202. http://dx.doi.org/10.1080/13549839708725524

Linn/Johnson Local Food Task Force. (2010). A bealthy seasonal local food plan for the Iowa Corridor Food \& Agriculture Coalition: Developing strategic partnerships to revitalize a local food system within the Iowa Corridor Region. Amana, Iowa: Linn/Johnson Local Food Task Force. http://www.iacorridor-localfood.org/ Projects $/$ Final $\% 20$ Strategic $\% 20$ Plan_final.pdf 
MacRae, R., Gallant, E., Patel, S., Michalak, M., Bunch, M., \& Schaffner, S. (2010). Could Toronto provide $10 \%$ of its fresh vegetable requirements from within its own boundaries? Matching consumption requirements with growing spaces. Journal of Agriculture, Food Systems, and Community Development, 1(2), 105-127.

http://dx.doi.org/10.5304/jafscd.2010.012.008

Mamen, K., Gorelick, S., Norberg-Hodge, H., \& Deumling, D. (2004). Ripe for change: Rethinking California's food economy. Berkeley, California: International Society for Ecology and Culture. http://www.localfutures.org/images/stories/pdf/ ripeforchange.pdf

Mari Gallagher Research \& Consulting Group. (2006). Examining the impact of food deserts on public bealth in Chicago. Chicago, Illinois: Author. http://www.marigallagher.com/site media/ dynamic/project files/1 ChicagoFoodDesert $\underline{\text { Report-Full .pdf }}$

Marin County Community Development Agency. (2007). Marin countywide plan. San Rafael, California: Author. http://co.marin.ca.us/depts/CD/main/ fm/cwpdocs/CWP CD2.pdf

Masi, B., Schaller, L., \& Shuman, M. H. (2010). The $25 \%$ shift: The benefits of food localization for Northeast Ohio \& how to realize them. Cleveland, Ohio: The Cleveland Foundation/The Northeast Ohio (NEO) Food Web. http://www.neofoodweb. org/sites/default/files/resources/the25shiftfoodlocalizationintheNEOregion.pdf

McClintock, N., \& Cooper, J. (2010). Cultivating the commons: An assessment of the potential for urban agriculture on Oakland's public land. Berkeley, California: City Slicker Farms, HOPE Collaborative, Institute for Food \& Development Policy (Food First). http://www.urbanfood.org/docs/ Cultivating the Commons2010.pdf

Meter, K. (2004). Fifty-year vision and indicators for a sustainable Minneapolis: Minneapolis sustainability roundtable. Minneapolis, Minnesota: Crossroads Resource Center. http://www.crcworks.org/indicators.pdf

Meter, K. (2006). Evaluating farm and food Systems in the US. In Williams, B., \& Imam, I. (Eds.), Systems concepts in evaluation: an expert anthology (pp. 141-159). Inverness, California: Edgepress.
Meter, K. (2007). Linked indicators of sustainability build bridges of trust. In C. A. Maida (Ed.), Sustainability and Communities of Place (Volume 5, Studies in environmental anthropology and ethnobiology) (pp. 183-200). Oxford, UK: Berghahn Books.

Meter, K. (2009). Mapping the Minnesota food industry. For Blue Cross and Blue Shield Minnesota Center for Prevention. Minneapolis, Minnesota: Crossroads Resource Center. http://www.crcworks.org/crcdocs/mnfood.pdf

Meter, K. (2010). Metrics from the field: Learning how to multiply. Journal of Agriculture, Food Systems, and Community Development, 1(2), 9-12. http://dx.doi.org/10.5304/jafscd.2010.012.014

Meter, K. (2011a). Metrics from the field: Breaking our chains. Journal of Agriculture, Food Systems, and Community Development, 1(4), 23-25. http://dx.doi.org/10.5304/jafscd.2011.014.008

Meter, K. (2011b). Obio's food systems: farms at the heart of it all. For University of Toledo Urban Affairs Center. Minneapolis, Minnesota: Crossroads Resource Center. http://www.crcworks.org/ohfood.pdf

Meter, K., \& Rosales, J. (2001). Finding food in farm country: The economics of food and farming in Southeast Minnesota. Lanesboro, Minnesota: Hiawatha's Pantry Project of the Community Design Center, Experiment in Rural Cooperation, Crossroads Resource Center. http://www.crcworks.org/ff.pdf

Mid-Ohio Regional Planning Commission, Agriculture and Food Systems Working Group. (2010). Central Ohio local food assessment and plan. Columbus, Ohio: MORPC/The Columbus Foundation. http://www.morpc.org/pdf/CentralOhioLocal FoodAssessmentAndPlan2010.pdf

Nagarajan, V., \& Okot-Uma, R. W. O. (1999). Environmental assessment of development projects: A guide for planners and managers. London, UK: Commonwealth Secretariat.

National Association of Development Organizations Research Foundation. (2011). Regional food systems infrastructure. Washington, D.C.: Author. http://www.nado.org/regional-food-systemsinfrastructure/

Percy-Smith, J. (1996). Introduction: Assessing needs. Theory and Practice. In J. Percy-Smith (Ed.), Needs assessment in public policy (pp. 3-10). Buckingham, UK: Open University Press. 
Peters, C. J., Bills, N. L., Lembo, A. J., Wilkins, J. L., \& Fick, G. W. (2009). Mapping potential foodsheds in New York State: A spatial model for evaluating the capacity to localize food production. Renewable Agriculture and Food Systems, 24(1), 72-84. http://dx.doi.org/10.1017/S1742170508002457

Peters, C. J., Bills, N., Wilkins, J. L., \& Smith, R. D. (2003a, February). Vegetable consumption, dietary guidelines, and agricultural production in New York State: Implications for local food economies. Smart Marketing. Ithaca, New York: Cornell University. http://hortmgt.dyson.cornell.edu/pdf/smart marketing/peters2-03.pdf

Peters, C. J., Bills, N., Wilkins, J. L., \& Smith, R. D. (2003b, September). Fruit consumption, dietary guidelines, and agricultural production in New York State: Implications for local food economies. Smart Marketing. Ithaca, New York: Cornell University. http://hortmgt.dyson.cornell.edu/pdf/smart marketing/peters9-03.pdf

Peters, C. J., Wilkins, J. L., \& Fick, G. L. (2007). Testing a complete-diet model for estimating the land resource requirements of food consumption and agricultural carrying capacity: The New York State example. Renewable Agriculture and Food Systems, 22(2), 145-153. http://dx.doi.org/10.1017/S1742170507001767

Pirog, R., Zdorkowski, G., Enshayan, K., Pardee, C., Meter, K., Beidler, K.,...Hug, A. (2006, August). Developing a vibrant and sustainable regional food system: Suggestions for community-based groups. Aldo Leopold Center for Sustainable Agriculture, Regional Food System Working Group, Iowa State University. Available at http://www.leopold.iastate.edu/pubsand-papers /2006-08-developing-vibrant-andsustainable-regional-food-system

Porter, M. E. (1995). The competitive advantage of the inner city. Harvard Business Review (May/June), 55+. http://www.uc.edu/cdc/Urban database/food resources/competitive-advantage-of-inner-city.pdf

Pothukuchi, K. (2004). Community food assessment: A first step in planning for community food security. Journal of Planning Education and Research, 23(4), 356-377. http://dx.doi.org/10.1177/0739456X04264908

Pothukuchi, K., \& Kaufman, J. L. (2000). The food system: A stranger to the planning field. Journal of the
American Planning Association, 66(2) 113-24. http://dx.doi.org/10.1080/01944360008976093

Pothukuchi, K., Joseph, H., Burton, H., \& Fisher, A. (2002). What's cooking in your food system? A guide to community food assessment. Venice, California: Community Food Security Coalition. http://www.foodsecurity.org/CFAguidewhatscookin.pdf

Sacramento Area Council of Governments. (2009). SACOG I-PLACE3S program. Sacramento, California: SACOG. http://www.sacog.org/ projects/attachments/modeling-tools/ Lizon PC\%20Present IPLACE3S.pdf

Second Harvest Food Bank. (2009). From the bayou to the boucherie: A food system assessment of South Louisiana. New Orleans, Louisiana: Author. http://repscottsimon.com/yahoo site admin/ assets/docs/A Food System Assessment of Sout h LA Introduction and Chapters 1.33131214.pdf

Slotterback, C. S., Forsyth, A., Krizek, K. J., Johnson, A., \& Pennucci, A. (2011). Testing three health impact assessment tools in planning: A process evaluation. Environmental Impact Assessment Review, 31(2), 144-153. http://dx.doi.org/10.1016/j.eiar.2010.01.005

Smith, C. R, Huber, P., \& Russell, M. (2007). Analyzing local food systems for success: Naming and graphing entrepreneurial and community based agriculture linkages. Des Moines, Iowa: Leopold Center for Sustainable Agriculture. http://www.leopold.iastate.edu/sites/ default/files/grants/2004-M04.pdf

Steinfield, H., Gerber, P., Wassenaar, T., Cassel, V., Mauricio, R., \& de Haan, C. (2006). Livestock's long shadow: Environmental issues and options. Rome, IT: Food and Agriculture Organization of the United Nations. ftp://ftp.fao.org/docrep/fao/010/ a0701e/a0701e00.pdf

Swenson, D. (2007). Economic impact summaries for local food production. Ames, Iowa: Iowa State University.

Swain, L. B. (1999). A study of the economic contribution of small farms to communities - completed 1996 to 1999. Unpublished manuscript, Rural Development Institute, University of Wisconsin-River Falls.

Swain, L. B., \& Kabes, D. (1998). 1996 community supported agriculture report. Unpublished manuscript, Rural Development Institute, University of Wisconsin-River Falls. 
Tchumtchoua, S., \& Lopez, R. A. (2005). A town-level assessment of community food security in Connecticut. Storrs, Connecticut: University of Connecticut, Food Marketing Policy Center. Research Monographs. No. 1. http://digitalcommons.uconn.edu/fpmc_mono/1 Thompson, E., Harper, A. M., \& Kraus, S. (2008). Think globally, eat locally: San Francisco foodshed assessment. Washington, D.C.: American Farmland Trust. http://www.farmlandinfo.org/documents/ 37187/ThinkGloballyEatLocally-FinalReport8-2308.pdf

Treuhaft, S., \& Karpyn, A. (2010). The grocery gap: Who has access to healthy food and why it matters. Oakland, California, \& Philadelphia, Pennsylvania: PolicyLink/The Food Trust. http://www.policylink.org/atf/cf/\%7B97C6D565BB43-406D-A6D5-ECA3BBF35AF0\%7D/ FINALGroceryGap.pdf

Unger, S., \& Wooten, H. (2006). A food systems assessment for Oakland, CA: Toward a sustainable food plan. Oakland, California: Mayor's Office of Sustainability. http://oaklandfoodsystem.pbworks. com/f/OFSA TOC ExecSumm.pdf

United States Department of Agriculture. (2011). Food desert locator. Washington, D.C.: USDA, Economic Research Service. http://www.ers.usda.gov/data/ fooddesert/index.htm
United States Department of Transportation. (2011). Freight Analysis Framework. Washington, D.C.: USDT, Federal Highway Administration. http://www.ops.fhwa.dot.gov/freight/freight analysis/faf/

Ver Ploeg, M., Breneman, V., Farrigan, T., Hamrick, K., Hopkins, D., Kaufman, P.,...\& Tuckermanty, E. (2009). Access to affordable and nutritious food: Measuring and understanding food deserts and their consequences. Report to the U. S. Congress. Washington D.C.: United States Department of Agriculture, Educational Research Service. Administrative report AP036. http://www.ers.usda.gov/publications/ap/ ap036/ap036.pdf

Vermont Sustainable Jobs Fund. (2011). Farm to Plate Strategic Plan. Montpelier, Vermont: Author. http://www.vsjf.org/assets/files/Agriculture/ Strat Plan/F2P\%20Executive\%20Summary 6.27.11 High $\% 20$ Quality.pdf

Williams, B., \& Imam, I. (Eds.). (2007). Systems concepts in evaluation: An expert anthology. Inverness, California: Edgepress.

Wolfson, M. (2010). Toronto's key industry clusters: Food \& beverage. Toronto, Ontario: City of Toronto. http://www.toronto.ca/invest-in-toronto/ food.htm 